\title{
Repeated Treatment with Haloperidol and Clozapine Exerts Differential Effects on Dye Coupling between Neurons in Subregions of Striatum and Nucleus Accumbens
}

\author{
Shao-Pii Onn and Anthony A. Grace \\ Departments of Neuroscience and Psychiatry, Center for Neuroscience, University of Pittsburgh, Pittsburgh, \\ Pennsylvania 15260
}

The delayed onset of action of antipsychotic drugs (APDs) during the treatment of schizophrenia has been hypothesized to temporally correlate with the induction of depolarization block in rat mesencephalic dopamine (DA) cell groups. Nevertheless, it is unknown whether these drugs also exert a delayed action on the dopaminoceptive postsynaptic target cells in the striatal complex. Using in vivo intracellular recording and dye labeling techniques, the effects of APDs on dye coupling were examined in subregions of the striatal complex defined by double staining for calbindin immunoreactivity. Rats treated repeatedly with APDs were found to exhibit a $66-71 \%$ higher incidence of coupling that occurred in a drug- and a region-specific manner, that is, both drug treatments increased dye coupling in the limbic-associated accumbens shell region whereas only haloperidol increased dye coupling in the motor-related striatal matrix and accumbens core regions. In addition, cells located in regions in which dye coupling was altered also showed significantly higher input resistance. These changes were not observed in response to DA receptor blockade by acute drug administration or when haloperidol was administered for a period sufficient to induce DA receptor supersensitivity but not DA cell depolarization block (i.e., 2 weeks). Therefore, alteration in dye coupling appears to be correlated temporally with the induction of DA cell depolarization block. The finding that both APDs exert a common action on neurons in the accumbens shell region is consistent with its identification as the site of therapeutic drug actions, whereas the capacity of haloperidol to also affect cells in the motor-related matrix and core regions correlates with its high propensity to induce extrapyramidal side effects.

[Key words: antipsychotic therapeutic action, extrapyramidal motor side effects, dopamine cell depolarization block, electrotonic transmission, accumbens core/shell regions, striatal matrix/patch compartments]

\footnotetext{
Received Mar. 17, 1995; revised June 20, 1995; accepted June 21, 1995.

We thank to Dr. M. R. Celio and Dr. H. T. Chang for their generous supplies of calbindin $28 \mathrm{Kd}$ and Lucifer yellow antisera, respectively. We also thank Mr. David Harden for his technical expertise in assessing the development of $D A$ cell depolarization block. This work was supported by USPHS MH45156, MH01055, and MH42217 and the Scottish Rite Schizophrenia Research Fund (to A.A.G.) and the National Alliance for Research into Schizophrenia and Affective Disorders (NARSAD) Young Investigator Award (to S.-P.O.).

Correspondence should be addressed to Dr. S. P. Onn, 464 Crawford Hall, Departments of Neuroscience and Psychiatry, Center for Neuroscience, University of Pittsburgh, Pittsburgh, PA 15260.

Copyright (C) 1995 Society for Neuroscience $0270-6474 / 95 / 157024-13 \$ 05.00 / 0$
}

Antipsychotic drugs (APDs) are dopamine (DA) receptor antagonists (Carlsson and Lindqvist, 1963) and their efficacy is highly correlated with their ability to block DA receptors (Creese et al., 1976; Seeman et al., 1976; Kebabian and Calne, 1979). Nonetheless, although APDs will block DA receptors within minutes following their administration (Rupniak et al., 1983; Sedvall et al., 1986), these drugs must be administered for weeks before achieving maximal therapeutic efficacy and before the Parkinsonian motor side effects are manifest (Spohn et al., 1977; Cotes et al., 1978; Davis and Garver, 1978; Johnstone et al., 1978; Cooper et al., 1990). The time-dependent effects of classic APDs in humans have been temporally correlated with the developInent of depolarization bluck of DA cell firing in rats, in which repeated haloperidol treatment causes a cessation of spontaneous spike discharge in the majority of mesencephalic DA neurons in the substantia nigra ( $\mathrm{SN}, \mathrm{A} 9)$ and the ventral tegmental area (VTA, A10) (Bunney and Grace, 1978; Chiodo and Bunney, 1983; White and Wang, 1983; Grace and Bunney, 1986). In contrast, repeated treatment with atypical antipsychotic drugs such as clozapine, which is not associated with extrapyramidal side effects in humans (Gerlach et al., 1974; Baldessarini and Tarsy, 1980; Kane et al., 1988), only causes an inactivation of VTA DA cell firing (Chiodo and Bunney, 1983; White and Wang, 1983). Therefore, the therapeutic actions and extrapyramidal side effects associated with antipsychotic drug administration correlate with the time course and regional selectivity of these drugs in inducing depolarization block of the mesolimbic and nigrostriatal DA neurons, respectively. Evidence has further shown that depolarization block occurs via time-dependent changes in feedback to the DA cells from postsynaptic sites (Bunney and Grace, 1978; Grace and Bunney, 1986; Hollerman et al., 1992), since acute transection of these pathways reverses depolarization block and lesioning of the striatal target cells prevents its development (Bunney and Grace, 1978; Chiodo and Bunney, 1983; White and Wang, 1983). However, it is not clear whether corresponding changes in the striatum occur in concert with DA cell depolarization block.

Dopannine is known to exert multifaceted actions within the striatal complex, including direct actions on striatal cell membranes (Arbuthnott et al., 1984; Bernardi et al., 1984; Calabresi et al., 1987, 1988) as well as modulatory effects on neurotransmitter release from afferent terminals (Mitchell and Doggett, 1980; Rowlands and Roberts, 1980; Maura et al., 1988; O'Donnell and Grace, 1994). In addition, several studies have described an action of DA beyond its effects on the activity of individual striatal cells, in which this neurotransmitter was 
shown to regulate the interactions within networks of striatal cell assemblies by modulating dye- and electrical-coupling among sets of striatal neurons in vitro (Cepeda et al., 1989; Walsh et al., 1989; O'Donnell and Grace, 1993) and in vivo (Onn and Grace, 1994a). Thus, in vivo recordings have shown that the administration of a behaviorally activating dose of the DI/D2 agonist apomorphine can dramatically increase the degree of dye coupling between striatal cclls (Onn and Gracc, 1994a).

In this study, the effects of repeated treatment for 1 month with haloperidol (1.5-3 mg/kg; i.p. daily) and clozapine (20 mg/ $\mathrm{kg}$ ) were examined with respect to their influence on dye coupling between striatal cells in the dorsal striatum and the nucleus accumbens using in vivo intracellular recording techniques. This dosage schedule and duration of drug treatment has been shown to be sufficient to induce DA cell depolarization block (Bunney and Grace, 1978; Chiodo and Bunney, 1983; White and Wang, 1983). Furthermore, to determine whether any alterations may correlate with the induction of DA receptor supersensitivity during APD treatment, the assessments were also carried out in rats that had been treated with haloperidol for 2 weeks, which is sufficient to cause DA receptor supersensitivity in the dorsal striatum (Burt et al., 1977; Muller and Seeman, 1978; Bannon et al., 1980) without inducing DA cell depolarization block (Chiodo and Bunney, 1983; White and Wang, 1983). Two dimensions of drug action were assessed: (1) their effect on the incidence and extent of dye coupling, and 2) their selectivity for neurons in the calbindin-positive motor regions (e.g., striatal matrix and accumbens core regions) or the calbindin-negative limbic regions (i.e., striatal patch and accumbens shell regions) of the striatal complex. The patch and matrix compartments of the dorsal striatum, which can be distinguished by their differential staining for calbindin immunoreactivity, are considered to represent distinct functional subdivisions of the striatum (Graybiel and Ragsdale, 1978, 1983; Goldman-Rakic, 1982; Gerfen, 1984; Gerfen et al., 1987; Graybiel, 1990): the striosomes are associated with the limbic component of the striatum (White, 1989) based on their cortical afferent innervation (Gerfen, 1984; Donoghue and Herkenham, 1986), whereas the matrix is more closely related to the extrapyramidal function of this region (Fairley and Marshall, 1986; Whishaw and Tomie, 1987; Pisa and Schranz, 1988; White, 1989; Francois et al., 1994). The nucleus accumbens has also been subdivided into two functional regions, termed the core and shell subregions, based on a proposed preferential involvement in sensorimotor integrative versus limbic functions, respectively (Mogenson et al., 1980; Alheid and Heimer, 1988; Zahm and Heimer, 1990; Heimer et al., 1991; Berendse et al., 1992; Cools et al., 1993; Prinssen et al., 1994). These subregions also show a differential staining for calbindin immunoreactivity (7ahm and Heimer, 1988; Voorn et al., 1989; Zahm, 1991).

Portions of these results have been presented in abstract form (Onn and Grace, 1994b,c).

\section{Materlals and Methods}

Animals. All procedures were carried out in accordance with the USPHS publication, Guide for the Care and Use of Laboratory Animals, and were approved by the Institutional Animal Care and Use Committee at the University of Pittsburgh. Male Sprague-Dawley rats $(N=73)$ weighing $175-250 \mathrm{gm}$ at the beginning of drug treatment were used.

Drug treatment. Either haloperidol or clozapine was administered to rats for 1 month ( $N=21$ for each drug) or for 2 weeks $(N=5$, haloperidol only) by injection (once per day, i.p.) or via the drinking water ( $N=4$ for each drug). Clozapine (RBI; Natick, MA) was first dissolved in $1 N \mathrm{HCl}$ and then titrated to $\mathrm{pH} 5.7-5.9$ with $1 \mathrm{~N} \mathrm{NaOH}$, with additional $0.9 \%$ saline added to achieve a final concentration of $1.4 \%$ (i.e., $0.043 \mathrm{M}$ ). Haloperidol (at $5 \mathrm{mg} / \mathrm{ml}$; McNeil Pharmaceuticals, Spring House, PA) was supplied in a vehicle solution containing lactic acid to adjust the $\mathrm{pH}$ to $3.0-3.6$. Haloperidol $(1.5-3 \mathrm{mg} / \mathrm{kg}$ ), clozapine $(19-21 \mathrm{mg} / \mathrm{kg}$ ) or saline solution (for controls, $n=8$ ) was administered for $30-40 \mathrm{~d}$ (defined as 1 month treatment in the following text). This drug administration protocol should have been sufficient to induce depolarization block in the mesencephalic DA cells (Bunney and Grace, 1978; Chiodo and Bunney, 1983; White and Wang, 1983). The rate of body weight gain in the drug-treated rats was not significantly different from the vehicle-treated controls, which typically gained approximately 150-250 gm above their initial weight during the 1 month treatment period. In a separate group of rats $(N=5)$, haloperidol was administered using a similar treatment protocol except that the rats were injected with the drug for a 2 week period, which should have been sufficient to induce DA D2 receptor supersensitivity (which is known to reach maximal at $7-10 \mathrm{~d}$ in the dorsal striatum with a similar regimen of haloperidol treatment; Burt et al., 1977; Muller and Seeman, 1978), but would be inadequate for the induction of DA cell depolarization block (Chiodo and Bunney, 1983; White and Wang, 1983). Since clozapine has not been shown to induce DA receptor supersensitivity (Kobayashi et al., 1978; Rupniak et al., 1985; See et al., 1989, 1994; Wilmot and Szczepanik, 1989; Dell et al., 1990; Florijn et al., 1994; Tarazi et al., 1994), only haloperidol was tested at this time point. To test the effects of acute drug administration, either clozapine $(N=5)$ or haloperidol $(N=5)$ was administered intravenously once on the day of recording at the same dose used in the repeated treatment paradigm.

Electrophysiology. Following repeated drug treatment, a $36 \mathrm{hr}$ drug wash-out period was allowed before recordings were performed. A drug washout period of $36 \mathrm{hr}$ was used in order to examine the changes induced during repeated administration, rather than the change in the response to acute drug administration. The animals were anesthetized with $8 \%$ chloral hydrate $(400 \mathrm{mg} / \mathrm{kg}$, i.p.) for in vivo intracellular recording and dye injection as previously described (Onn and Grace, 1994a; Onn et al., 1994a-c). Intracellular recording microelectrodes that had been pulled on a Flaming/Brown P80/PC electrode puller and filled with Lucifer yellow (10\% Lucifer yellow dissolved in $1 \mathrm{M} \mathrm{LiCl}$; average input resistance $=110-150 \mathrm{M} \Omega$ ) were lowered into the brain to record from neurons in the dorsal striatum and nucleus accumbens at the following stereotaxic coordinates: AP, $0 \mathrm{~mm}$ to $2 \mathrm{~mm}$ anterior to bregma; ML, $1.5 \mathrm{~mm}$ to $3.6 \mathrm{~mm}$ from the sagittal suture; and DV, $3 \mathrm{~mm}$ to 7.8 $\mathrm{mm}$ from the dura. Spontaneous basal activity was collected at the resting membrane potential for each striatal neuron impaled. Cell input resistance was calculated by measuring the membrane voltage deflections produced in response to $100-150 \mathrm{msec}$ duration constant current pulses delivered across a bridge circuit integral to the preamplifier. The amplitude of the constant current pulses used in this calculation ranged between $1 \mathrm{nA}$ in the hyperpolarizing direction and depolarizing current pulses that were subthreshold for triggering spike discharge. Action potential amplitude was measured as the difference between the resting membrane potential and the spike peak.

Intracellular labeling with Lucifer yellow. After achieving a stable impalement, striatal neurons were stained using Lucifer yellow-filled electrodes by injecting $1-3 \mathrm{nA}$ constant hyperpolarizing current interrupted by short duration (5-10 $\mathrm{msec})$ depolarizing pulses delivered at 4-7 $\mathrm{Hz}$ into the electrode (Grace and Llinas, 1985; Grace and Onn, 1989; Onn and Grace, 1994a; Onn et al., 1994c). During dye injection, the electrode was not moved and the cell membrane potential was closely monitored to maintain a stable penetration and to ensure that only a single cell was injected with dye. All cells used to evaluate the incidence of dye coupling were injected for a minimum of $3 \mathrm{~min}$, with some injections lasting up to $15 \mathrm{~min}$. The amount of time that elapsed between the injection of dye and perfusion of the rat ranged between 5 min and $4 \mathrm{hr}$ and was noted for each cell injected. In general, postinjection survival time did not show any correlation with the presence of dye coupling in cells that were injected for at least $3 \mathrm{~min}$, as reported previously (Onn and Grace, 1994a). After completion of the recordings, the deeply anesthetized rats were perfused transcardially with saline followed by $500 \mathrm{ml}$ of $4 \%$ buffered paraformaldehyde $(\mathrm{pH}=7.4)$. Frontal or sagittal sections $(60 \mu \mathrm{m}$ in thickness) were cut in series on a freezing microtome and collected in $0.1 \mathrm{M}$ phosphate buffer ( $\mathrm{pH} 7.4$ ). Lucifer yellow-labeled cells were examined using a Leitz Orthoplan II epifluorescence microscope equipped with a Leitz I3 filter cube (excitation: band pass 355-425 nm; dichromatic mirror: RKP $580 \mathrm{~nm}$; sup- 
Table 1. Effects of repeated treatment with haloperidol and clozapine on the incidence of dye coupling between spiny cells in striatal matrix/patch and accumbens core/shell regions

\begin{tabular}{|c|c|c|c|c|c|c|}
\hline $\begin{array}{l}\text { Striatal } \\
\text { subregions }\end{array}$ & $\begin{array}{l}\text { Basal } \\
\text { levels }{ }^{b}\end{array}$ & $\begin{array}{l}\text { Acute } \\
\text { HAL } \\
\text { (i.v.) }\end{array}$ & $\begin{array}{l}\text { Repeated } \\
\text { HAL } \\
\text { (2 wks) }\end{array}$ & $\begin{array}{l}\text { Repeated } \\
\text { HAL } \\
\text { (1 mon.) }\end{array}$ & $\begin{array}{l}\text { Acute } \\
\text { CLZ } \\
\text { (i.v.) }\end{array}$ & $\begin{array}{l}\text { Repeated } \\
\text { CLZ } \\
\text { (1 mon.) }\end{array}$ \\
\hline Striatal matrix & $2 / 12(17 \%)$ & $1 / 6(14 \%)$ & $1 / 7(14 \%)$ & $\begin{array}{l}4 / 8(50 \%) \\
p=0.047\end{array}$ & $0 / 5(0 \%)$ & $1 / 10(10 \%)$ \\
\hline Striatal patch & $0 / 5(0 \%)$ & N.T. & N.T. & $0 / 3(0 \%)$ & N.T. & $0 / 3(0 \%)$ \\
\hline Accumbens core & $2 / 9(22 \%)$ & $2 / 7(28 \%)$ & $1 / 5(20 \%)$ & $\begin{array}{l}4 / 6(67 \%) \\
p=0.06\end{array}$ & $1 / 7(14 \%)$ & $4 / 9(44 \%)$ \\
\hline Accumbens shell & $1 / 10(10 \%)$ & $0 / 6(0 \%)$ & $1 / 7(14 \%)$ & $\begin{array}{l}4 / 6(67 \%) \\
p=0.0001\end{array}$ & $0 / 5(0 \%)$ & $\begin{array}{l}5 / 7 \quad(71 \%) \\
p=0.0001\end{array}$ \\
\hline
\end{tabular}

$p$ values determined by the Fisher exact test in comparison with control.

${ }^{a}$ Determined by calbindin immunoreactivity counterstain.

${ }^{b}$ Percentage injections resulting in coupling = number of cases of coupling/number of cells injected.

pression: low pass $580 \mathrm{~nm}$ ). Cells were scored as dye coupled when the injection of a single cell resulted in the labeling of more than one cell. This typically consisted of the labeling of two or three cells with the somata located in one or two adjacent sections and dendritic processes spanning across the remaining threc to scven scctions.

Immunocytochemical double-labeling for calbindin. Lucifer yellowlabeled cells were also characterized with respect to their location within the motor- (matrix/core) or limbic- (patch/shell) related subregions of the striatal complex by double labeling for calbindin immunoreactivity. This was done using the Texas red indirect fluorescence method as described previously (Onn and Grace, 1994a; Onn et al., 1994c). Briefly, serial sections containing Lucifer yellow-labeled cells were processed with calbindin $28 \mathrm{Kd}$ antisera raised in mouse (a gift of Dr. M. $\mathrm{R}$. Celio; at $2000 \times$ dilution with $0.1 \mathrm{M}$ phosphate buffer containing $0.4 \%$ Triton X-100 and 5\% normal horse serum) followed in sequence by incubation with biotinylated horse- anti-mouse IgG (at $100 \times$ dilution) for $4 \mathrm{hr}$ and by incubation with Texas red-conjugated avidin (at $100 \times$ dilution) overnight at $4^{\circ} \mathrm{C}$. For dual light field examination, the avidin/biotin complex system (ABC system; Vector) was used to convert the Lucifer yellow and the calbindin fluorescent labels to dualcolor peroxidase stains. The double-labeled sections were then examined using a Leitz Orthoplan II microscope configured for light field illumination (for the dual peroxidase-stained sections) or for epifluorescence illumination under I3 (Lucifer yellow) and N2 (rhodamine) filter cubes (for the double fluorescence-labeled sections; N2 cube-excitation: band pass $530-560 \mathrm{~nm}$; dichromatic mirror: RKP $580 \mathrm{~nm}$; suppression: low pass $580 \mathrm{~nm}$ ).

Statistics. The incidence of dye coupling between neurons in the experimental groups was compared using a nonparametric Fisher exact test. Student's $t$ test was used to test for differences between means of unpaired observations. Data are expressed as mean \pm standard deviation.

\section{Results}

Several studies have shown that dye coupling can be a reliable indicator of the presence of gap junction connections between neurons (Andrew et al., 1981, 1982; MacVicar and Dudek, 1981, 1982; Dudek et al., 1983; Llinas, 1985; O’Beirne et al., 1987; Phelan et al., 1993) provided that sufficient caution is used when employing this technique (Gutnick and Prince, 1981; Grace and Bunney, 1983; Gutnick et al., 1985; O'Donnell and Grace, 1993; Onn and Grace, 1994a). It has been our experience that consistent dye coupling assessments require that stable penctrations bc maintained throughout the dye injection period (Onn and Grace, 1994a). Therefore, to obtain consistent data and to circumvent the introduction of some potential artifacts, data were only collected from neurons that met the following criteria: (1) after penetration the cell exhibited a stable resting membrane potential of $-60 \mathrm{mV}$ or greater, and action potential amplitudes of $55 \mathrm{mV}$ or greater; (2) cells were injected with dye for a minimum of 3 min, with the penetration remaining stable throughout the injection periods; (3) there was complete filling of the soma and dendritic processes of each cell comprising a coupled set; (4) all cells labeled by a single injection exhihited an equal intensity

Figure 1. Photomicrographs illustrating the typical pattern of single neuronal labeling following intracellular injection of the dye Lucifer yellow into neurons in the accumbens core $(A)$ and shell $(B)$ regions as well as in the striatal patch region $(C)$. $A$, Injection of a single cell in the accumbens core region results in the labeling of one neuron with Lucifer yellow. Al, A Lucifer yellow-labeled spiny neuron shown in the coronal plane had a medium-sized soma (arrow; $14 \mu \mathrm{m}$ in diameter) and extensive local axonal collateralization (open arrows). A2, Subsequent staining of the same section $(A 1)$ for calbindin immunoreactivity reveals that the neuron is confined completely within the border (arrowheads) of the calbindin-positive core region. Calbindin immunoreactivity is indicated by the presence of Texas red fluorescence and the brain slice is examined using a Leitz I3 filter cube. A3, The location of the Lucifer yellow-labeled cell (not seen; asterisk indicates location of the soma) is shown in relation to the core and shell subdivisions in the same section $(\dot{A} 2)$ illuminated using the Leitz N2 filter cube selective for Texas red fluorescence. Anterior commissure $(a c)$; insular cortex $(C x) . B$, Injection of a single cell in the nucleus accumbens shell region results in the staining of one medium spiny neuron. $B 1$, A single Lucifer yellow-labeled spiny neurons shown in the sagittal plane exhibits a $16 \mu \mathrm{m}$ diameter soma (arrow) that gave rise to an axon (open arrowhead) and extensive axonal collaterals in adjacent sections (not shown). B2, subsequent conversion of the Lucifer ycllow fluorescence into a peroxidase stain in the same section $(B 1)$ by immunocytochemical localization of Lucifer yellow. B3, when this same section $(B 2)$ was subsequently stained for calbindin immunoreactivity, the neuron (arrow) was found to be confined completely within the calbindin-negative shell region (arrowheads mark the border to the core region). $C$, Injection of a single cell with Lucifer yellow in the striatal patch region labels one medium spiny cell. Cl, A single Lucifer yellow-labeled spiny neuron shown in the coronal plane has a $17 \mu \mathrm{m}$ diameter soma (arrow) and an axon (open arrowhead) that originates from one of its primary dendrites; the axon (open arrow) also was found to give rise to extensive axonal collaterals in adjacent sections (not shown). $C 2$, Subsequent staining of this section $(C l)$ for calbindin immunoreactivity reveals that this neuron and its dendritic processes are confined completely within the border (arrowheads) of a calbindin-negative patch region (i.e., Texas red poor zone). C3, Examining this section $(C 2)$ using a Texas red filter cube (Leitz N2 filter cube) illustrates the relationship of this cell (*) to the boundary of the matrix/patch structure. $i c$, Internal capsule. Scale bars, $50 \mu \mathrm{m}$ for all figures. $A 1, B 1, C 1$ refer to bar in $C 1 ; A 2$ refers to bar in $A 2 ; B 2, C 2, A 3$, $B 3, C 3$ refer to bar in $C 3$. 


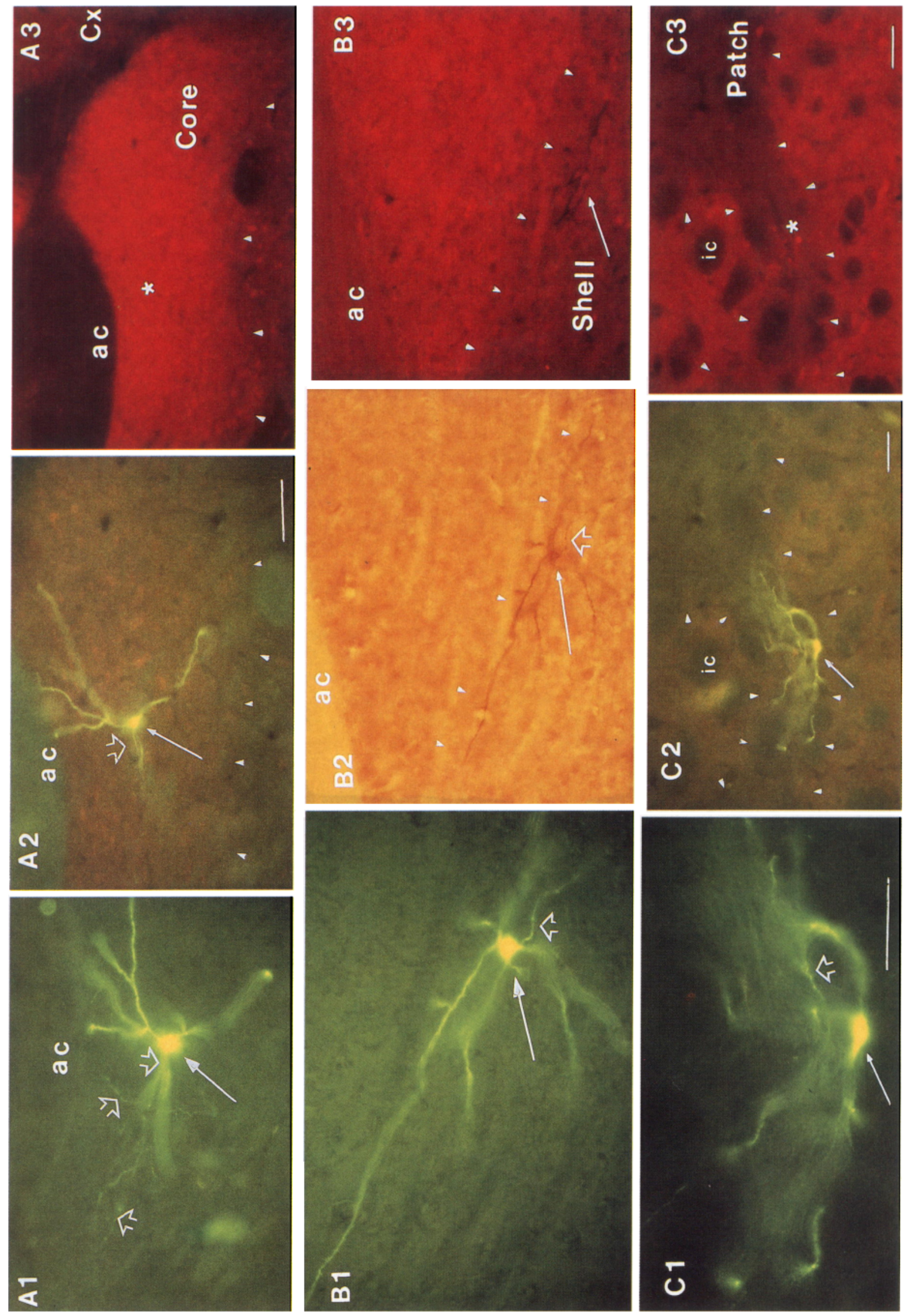


of Lucifer yellow fluorescence; and (5) there was no evidence of extracellular spillage of dye in the vicinity of the stained cells.

In accordance with these restrictions, the present results were drawn from a total of 146 Lucifer yellow injections into striatal spiny cells (i.e., the Spiny I cell class): 36 injections in control or saline-treated rats and 110 injections in haloperidol- or clozapine-treated rats (acute drug $=37 ; 1$ month drug administration $=54 ; 2$ weeks drug administration $=19$ ). In addition to this sample, six of the cells injected exhibited a morphology that was not of the Spiny I morphological cell class (DiFiglia et al., 1976; Preston et al., 1980; Bishop et al., 1982; Chang et al., 1982; Fisher et al., 1986; Yelnik et al., 1991; Onn et al., 1994c). Since aspiny or sparsely spined cells have not been observed to exhibit dye coupling in control rats or following acute treatment with DA agonists (Onn and Grace, 1994a), they were not included in the data used to calculate the incidence of dye coupling in these experiments.

\section{Pattern and incidence of dye coupling in subregions of the striatal complex in vehicle-treated control rats}

Out of a total of 36 striatal cells injected with Lucifer yellow in 8 vehicle-treated control rats, 5 injections resulted in the labeling of single pairs of neurons, which corresponds to a $14 \%$ incidence of dye coupling (Table 1). If the calculation is performed to include the data from all control rats studied to date $(N=112$; $N=36$ from present results plus $N=76$ from Onn and Grace, 1994a), the overall incidence of coupling is $16 \%$ (i.e., 18 single pairs). For each labeled cell, Lucifer yellow was injected for a minimum of $3 \mathrm{~min}$ with an average time of injection of $6.3 \pm$ 2.5 min (mean $\pm \mathrm{SD} ; N=146$; range $=3-15 \mathrm{~min}$ ). The average length of time that dye was injected into cells that were subsequently revealed to be dye coupled $(6.7 \pm 2.7 \mathrm{~min} ; N=34)$ was not significantly different from those cases in which the injections only yielded single-labeled cells $(6.0 \pm 3.1 \mathrm{~min} ; N=$ $112 ; t=-0.32 ; \mathrm{df}=144 ; p>0.7 ; \mathrm{NS})$, which is consistent with our previous report (Onn and Grace, 1994a).

Cells labeled by Lucifer yellow injection were analyzed with respect to their location within striatal subregions (i.e., matrix/ patch or accumbens core/shell regions) by further processing the tissues for calbindin-28 Kd immunoreactivity. In the majority of cases, injections of cells in the control striatal complex resulted in the labeling of single spiny cells which typically had their dendritic processes restricted to the same region or compartment in which the cell bodies were located (Fig. $1 A-C$ ). This is particularly evident for cells stained at the border of two adjacent regions; for example, between accumbens core and shell regions (Гig. $1 A, B$ ) or between striatal matrix and patch structures (Fig. $1 C)$. Based on cells that were double labeled for calbindin immunoreactivity, approximately $58 \%(21 / 36)$ of the cells stained with Lucifer yellow were located in calbindin-rich regions, with $57 \%(12 / 21)$ of these located in the striatal matrix and $43 \%(9 /$ $21)$ in the accumbens core region. The remaining $42 \%(15 / 36)$ of the Lucifer yellow-stained cells were located in calbindinnegative regions [patch: $33 \%$ (5/15); shell: $66 \%(10 / 15)]$. There was an approximately equal incidence of coupling observed in the striatal matrix $(17 \% ; 2 / 12)$ and the accumbens core region $(22 \% ; 2 / 9)$. In contrast, cells labeled in calbindin-negative striatal patch and accumbens shell regions exhibited comparatively low incidences of coupling (i.e., patch: 0/5; shell: 1/10; Table $1)$.

As reported previously (Onn and Grace, 1994a), all cases of dye coupling observed in the vehicle-treated control rats were found to occur only between cells of the same morphological class; that is, the Spiny I cell class. In almost all cases, coupling occurred only between pairs of cells; coupling involving sets of three cells was only observed in four cases across all groups, and in each case the cells were located in the ventral core region (i.e., ventral to anterior commissure) of the accumbens. In the majority of cases, the points of contact among coupled neurons occurred between the primary or between the secondary dendritic processes of the cells. Direct apposition between the somata of coupled cells was rarely observed. In all three subregions that exhibited dye coupling in controls, the somata and the dendritic processes of dye-coupled cells were confined to a single compartment, as reported previously (Onn and Grace, 1994a).

\section{Effects of acute versus 1 month repeated administration of haloperidol on dye coupling in subregions of the striatal complex}

Animals treated acutely with haloperidol $(2-3 \mathrm{mg} / \mathrm{kg} ;$ i.v.) did not exhibit significant differences in the incidence of dye coupling observed in the striatal matrix (1/6) or accumbens core (2/ 7 ) and shell $(0 / 6)$ regions as compared to vehicle-treated controls. However, following repeated treatment with haloperidol for 1 month there was nearly a fourfold higher incidence of dye coupling in the striatal complex, with $52 \%(12 / 23)$ of the cells injected exhibiting coupling. Coupling was particularly high in the striatal matrix region $(50 \% ; 4 / 8 ; p=0.047$; Onn and Grace, $1994 \mathrm{a})$ and in the accumbens core region $(67 \% ; 4 / 6 ; p=0.06$; Fig. $2 A, B)$. The number of cells coupled per injection in the matrix compartment was identical to that found in the vehicletreated control group (i.e., two cells coupled in every case examined). Similarly, the pattern of coupling was not altered in the accumbens core region [average $2.3 \pm 0.5$ for both HAL/ CLZ (6 pairs, 2 triplets) vs $2.5 \pm 0.7$ for control ( 1 pair, I triplet), $t=0.45 ; p>0.7$ NS] since in both control and haloperidol-treated groups approximately $50 \%$ (control: $1 / 2$; HALtreated: $2 / 4$ ) of the cases of coupling in the core region occurred among sets of three cells (Fig. $2 B$ ). In addition to exhibiting a higher incidence of dye coupling in both the matrix and core regions, rats treated with haloperidol for 1 month also exhibited a higher incidence of dye coupling in the ventrally located calbindin-poor shell region (4/6 or $67 \%$ ). Although the incidence of coupling found in the shell of HAL-treated rats was similar to that observed in the matrix and core regions of these rats, it represents more than a fivefold increase in coupling when the comparatively low level of coupling found in the shell of controls is taken into account (i.e., $10 \% ; p<0.0001$ ). Similar to that observed in the core and matrix regions, the average number of cells coupled per injection in the shell region was the same as that observed in controls $[2.1 \pm 0.3$ vs $2.0 \pm 0.0(N=1)]$.

As in controls, in all cases of dye coupling examined in the treated rats the cells exhibited a medium spiny morphology and the sites of direct contact between coupled neurons was limited to the dendritic regions. The somata and dendritic processes of the dye-coupled neurons did not cross the boundary between two adjacent subregions, that is, between patch and matrix structures or between accumbens core and shell subregions (Fig. $2 B, C)$. Therefore, despite the higher incidence of dye coupling observed in the calbindin-rich matrix and core regions as well as in the calbindin-poor accumbens shell region following repeated HAL treatment, the pattern and the extent (i.e., the number of cells labeled per injection) of coupling was unchanged. 
In summary, the incidence of dye coupling was higher in both the motor-related matrix and core regions as well as in the limbic-related shell regions in rats that had received repeated treatment with haloperidol for 1 month; no changes in the patch/ matrix distribution or in the extent of coupling were observed.

Effects of acute versus 1 month repeated clozapine administration on dye coupling in subregions of the striatal complex

As found with acute haloperidol administration, the incidence or extent of dye coupling observed in rats receiving a single injection of clozapine was not significantly different from that found in either the matrix or in the core/shell region of controls $(0 / 5$ matrix; $1 / 7$ core; $0 / 5$ shell; $p>0.8$ ). However, in contrast to the rats receiving repeated $\mathrm{HAL}$, the level of dye coupling observed in the calbindin-positive matrix and core regions of rats that had becn treated with clozapine for 1 month was the same as that observed in controls (i.e., calbindin- positive matrix $=10 \%(1 /$ 10 ) and core $=44 \%(4 / 9) ; p>0.5$ vs controls; NS; Table 1 ). In contrast, the incidence of coupling observed in the shell region of clozapine-treated rats was $71 \%(5 / 7)$, which was more than sevenfold higher than that observed in vehicle-treated controls $(P=0.0001)$, but not significantly different from that found following repeated HAL $(P>0.7 ; \mathrm{NS})$. Furthermore, except for a single case, the extent of coupling in clozapine-treated rats did not extend beyond two cells coupled per injection in this region. In all cases examined, each of the coupled cells exhibited a spiny morphology and did not cross the boundary between the calbindin-negative shell region and the calbindin-positive core region (Fig. 2C).

\section{Effects of 2 week treatment with haloperidol on dye coupling}

$\Lambda$ s outlined in Materials and Methods, a 1 month period of haloperidol treatment should have been sufficient to induce both DA cell depolarization block and DA supersensitivity in the striatum. In order to segregate the responses that may be correlated with the time course of these events, a separate group of rats was tested after 2 weeks of HAL treatment, which was shown to be sufficient to induce DA supersensitivity (Burt et al., 1977; Muller and Seeman, 1978; Bannon et al., 1980) without causing DA cell depolarization block (Chiodo and Bunney, 1983; White and Wang, 1983). In contrast to the 1 month treatment effects, 2 weeks of treatment failed to alter the incidence of dye coupling from that observed in controls ( $1 / 7$ matrix; $1 / 5$ core; $1 / 7$ shell; $p>0.7$ in each region, Table 1$)$.

\section{Effects of 1 month treatment with antipsychotic drugs on dye coupling within the striatal patch region and on dye coupling between aspiny cells}

Unlike spiny cells in the striatal matrix and in the accumbens core and shell regions, none of the cells that were labeled within the patch compartment of control rats or rats treated with antipsychotic drugs for 1 month $(N=5$ controls and $N=3$ each drug; total $=11$ ) were found to exhibit dye coupling. The comparatively small volume and irregular locations of the patch compartments (i.c., 5-15\% of the striatal tissue volume; Groves et al., 1988; Desban et al., 1989) limited the number of dyeinjected cells that could be labeled in this region; therefore, a quantitative evaluation of the basal levels of coupling and its modulation by drug treatment could not be accurately determined from these data. However, all of the single-labeled spiny cells located in the patch compartment also restricted their den- dritic processes to the same compartment in which the soma was located.

I ucifer yellow labeling of aspiny cells did not result in dye coupling in the striatum of control or treated rats (i.e., 1 month repeated treatment with either APD; $N=3$ for each) Due to the comparatively low percentage of aspiny cells in the striatum (i.e., 1-5\% of striatal cells; Pasik et al., 1977, 1979; Preston et al., 1980; Graybiel and Ragsdale, 1983; Fisher et al., 1986; Kawaguchi et al., 1992), a sample size that was sufficiently large to evaluate the extent of coupling in control or treated rats could not be collected. Nonetheless, even in regions in which APD treatment caused the majority of spiny cells to exhibit dye coupling, in no instance was coupling observed between aspiny cells.

\section{Electrophysiological properties of striatal spiny cells in rats following 1 month treatment with either haloperidol or clozapine}

Spiny neurons recorded in rats that had been treated for 1 month with either antipsychotic drug had resting membrane potentials that were not significantly different from those of cells recorded in control rats (HAL: $-64.4 \pm 9.6 \mathrm{mV}, N=23$; CLZ: -66.2 $\pm 13.8 \mathrm{mV}, N=29$; vs Controls: $-69.1 \pm 7.7 \mathrm{mV}, N=36 ; t$ $=1.38$ for HAL and $t=0.62$ for CLZ vs controls; NS). Nevertheless, the striatal cells recorded in regions that also exhibited high levels of dye coupling in the 1 month drug-treated rats were found to have a significantly higher input resistance, which averaged $86.2 \% \pm 5.2 \%$ above that of controls (drug-treated: $\mathrm{HAL}=56.8 \pm 19.8 \mathrm{M} \Omega N=8 ; \mathrm{CLZ}=67.7 \pm 29.8 \mathrm{M} \Omega N$ $=6$; vs controls $=32.4 \pm 12.6 \mathrm{M} \Omega N=14 ; t=-3.56$ for HAL and $t=-3.83$ for CLZ vs controls, Fig. 3). However, within a given region the input resistance of a single cell was not correlated with the presence of dye coupling in that cell, which is consistent with that observed in comparisons between single-labeled and dye-coupled cells of control rats both in the present study and in our previous report (Onn and Grace, 1994a).

\section{Discussion}

As reviewed in the introductory section, although antipsychotic drugs will produce a maximal blockade of DA receptors within minutes of their administration, many of their clinical actions require weeks of treatment before they are fully expressed (Pickar et al., 1984). In animal studies, at least two responses to antipsychotic drugs have been shown to occur over the time course of repeated APD treatment: (1) DA receptor supersensitivity - an increase in the density of DA receptors that appears to be limited to treatment with classical APDs (Burt et al., 1977; Muller and Seeman, 1978; Rupniak et al., 1985; See et al., 1989, 1994; Wilmot and Szczepanik, 1989; O’Dell, 1990; Florijn et al., 1994) and reaches near maximal levels by 1-2 weeks after initiating treatment (Burt et al., 1977; Muller and Seeman, 1978), and (2) DA cell depolarization block-a cessation of DA cell firing in mesencephalic SN and VTA DA cells, which requires repeated administration for 3 weeks or longer to develop (Bunney and Grace, 1978; Chiodo and Bunney, 1983; White and Wang, 1983). In this study, we have found a regionally selective increase in dye coupling between striatal spiny neurons of rats that correlates with the time course of the development of DA cell depolarization block. 
7030 Onn and Grace • Antipsychotic Drugs Increased Dye Coupling in Striatal Complex
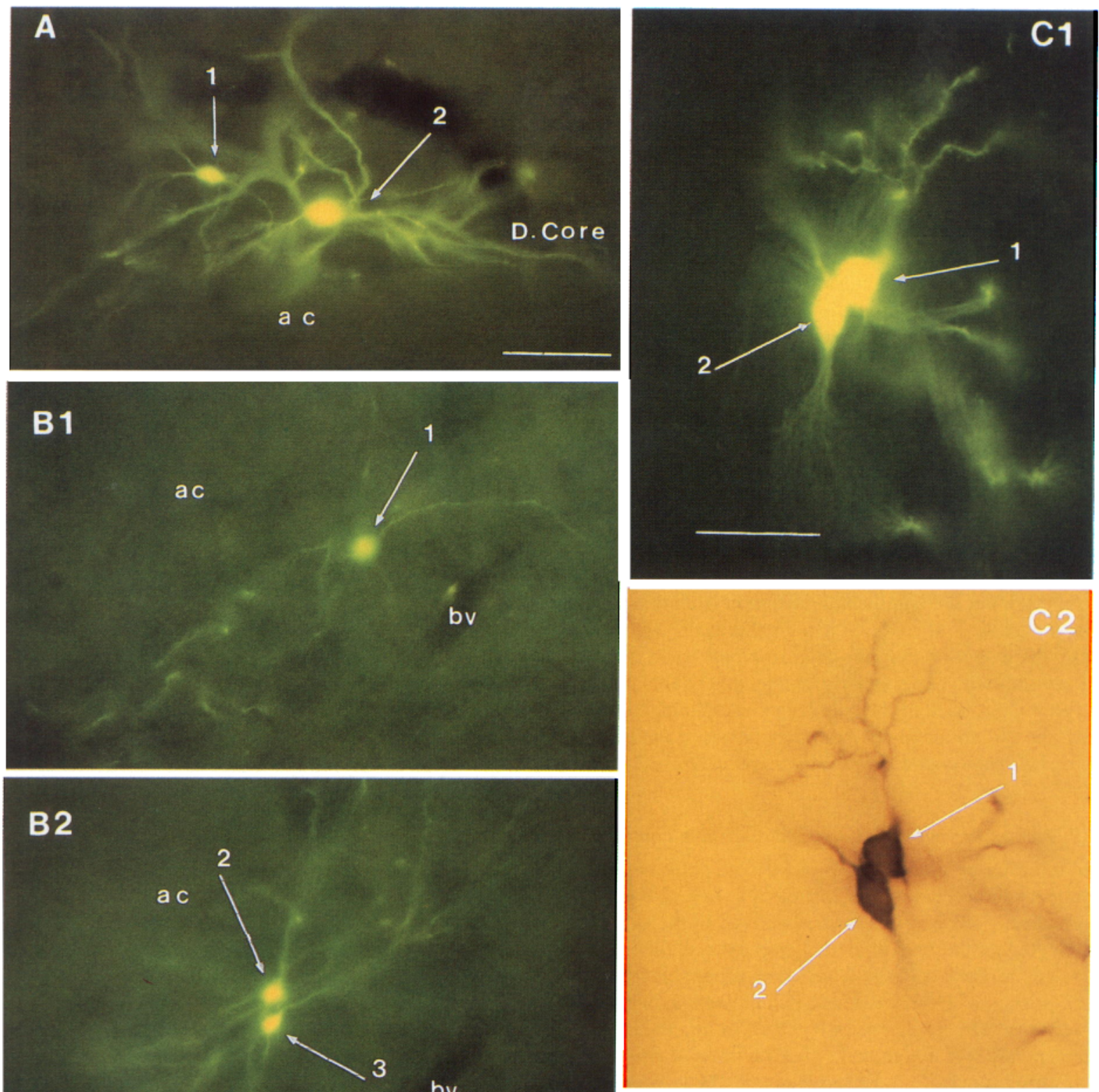

bv

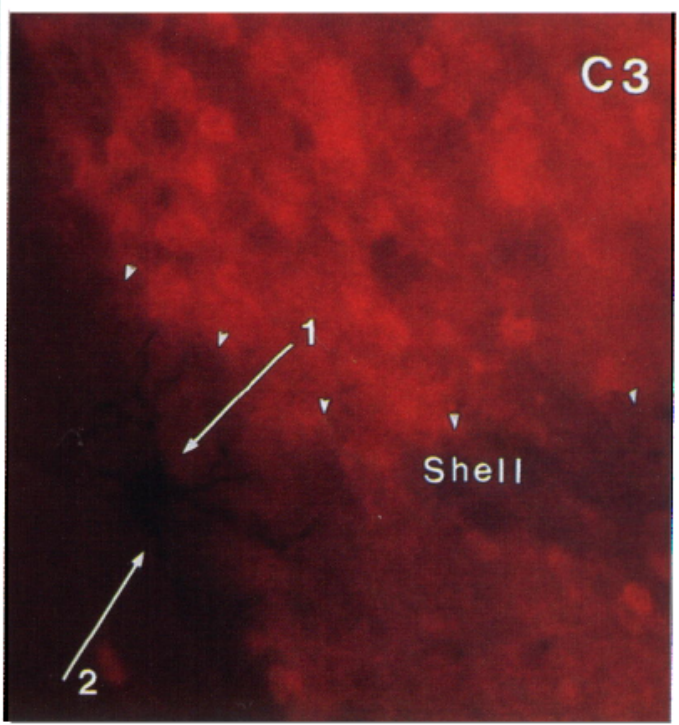

Figure 2. Photomicrographs illustrating patterns of dye-coupled cells in the accumbens core $(A, B)$ and shell $(C)$ regions following injection of single cells with Lucifer yellow in rats that had received 1 month of antipsychotic drug treatment. $A$, In haloperidol-treated rats, injection of a 
Dye coupling in the adult striatal complex of vehicle-treated controls

In the adult striatal complex, intracellular injection of dye into striatal cells resulted primarily in the labeling of single spiny neurons. The dendritic arborizations of the labeled spiny cells were strictly confined to the same compartment or region in which the parent somata resided (Penny et al., 1988; Arts and Groenewegen, 1992; Onn and Grace, 1994a; Onn et al., 1994c). In the present study, dye coupling was found to occur in substantial levels (approximately $20 \%$ of the cells injected) in the calbindin-positive striatal matrix and accumbens core regions, which was similar to the levels we observed previously during in vivo (Onn et al., 1990; Onn and Grace, 1994a) and in vitro (O'Donnell and Grace, 1993) recordings. With respect to the extent of dye coupling (i.e., the number of cells coupled per injection), we have consistently found coupling to occur only between pairs of striatal cells in control rats. In contrast, in the ventral core region (i.e., the calbindin-positive region ventral to the anterior commissure), approximately one-third of the coupling was observed to occur among sets of three cells. The incidence of coupling was found to be lower in the calbindinnegative regions (i.e., striatal patch and accumbens shell regions) when compared to the calbindin-rich matrix and core regions. Although the reason for this difference is unclear, the regions (i.e., the patch or the shell regions) that exhibited a trend toward lower incidences of coupling in the present study correspond to the areas that have been shown by others to have higher levels of DA activity (Graybiel et al, 1978, 1983; Deutch and Cameron, 1992) or DA fibers (Voorn et al., 1986; Zahm, 1992; Meredith et al., 1994). Furthermore, this inverse relationship between coupling and extracellular DA levels is further supported by recent studies showing the presence of significantly higher levels of coupling in the DA depleted adult striatum (Cepeda et al., 1989; Onn and Grace, 1993) as well as in the developing striatum before the dopamine afferentation is complete (Walsh et al., 1989).

\section{Differential modulation of dye coupling by typical versus atypical antipsychotic drugs}

Acute administration of either haloperidol or clozapine did not significantly affect the level of coupling in the striatal subregions examined. In contrast, following 1 month repeated administration of haloperidol or clozapine, significantly higher levels of coupling were detected in the striatal complex in a regionally specific manner. Repeated treatment with haloperidol for 1 month increased the levels of coupling by four- to sevenfold in both motor (matrix/core)- and limbic (shell)-related striatal subregions, whereas 1 month treatment with clozapine only increased the incidence of coupling in the limbic-associated accumbens shell region. The fact that coupling was altered only in rats that had received repeated drug treatment suggests the involvement of a time-dependent alteration in the DA system that occurs beyond the initial DA receptor blockade that is present within minutes following acute drug administration (Rupniak et al., 1983; Sedvall et al., 1986).

Studies have shown that there are at least two time-dependent changes that occur in the DA system with repeated HAL administration: an increase in the number of DA receptors in the striatum (Burt et al., 1977; Muller and Seeman, 1978; Rupniak et al., 1985; Wilmot and Szczepanik, 1989; O'Dell et al., 1990; See et al., 1994; Tarazi et al,, 1994) and depolarization block of mesencephalic DA cell firing (Bunney and Grace, 1978; Chiodo and Bunney, 1983; White and Wang, 1983; Grace and Bunney, 1986). Thus, DA D2 receptor supersensitivity is known to develop following approximately 1 week of treatment with haloperidol but not with clozapine (Burt et al., 1977; Kobayashi et al., 1978; Muller and Sccman, 1978) and appcars to be present in a homogenous pattern throughout the extent of the dorsal striatum (Burt et al., 1977; Miller and Seeman, 1978; Rupniak et al., 1985; Wilmot and Szczepanik, 1989; O'Dell et al., 1990) but not in the nucleus accumbens (Wilmot and Szczepanik, 1989; O'Dell et al., 1990; Florijn et al., 1994; See et al., 1994; Tarazi et al., 1994). On the other hand, the development of DA cell depolarization block occurs only following repeated treatment for at least $21 \mathrm{~d}$ with either haloperidol or clozapine (Chiodo and Bunney, 1983; White and Wang, 1983). In order to dissociate any effects on coupling arising from D2 supersensitivity from those requiring a longer treatment period, the level of coupling was also assessed after 2 weeks of treatment with haloperidol. In contrast to the increased coupling observed with 1 month of antipsychotic drug treatment, administration of haloperidol for only 2 weeks did not result in any significant alterations in the incidence of coupling in any of the subregions examined. Although several mechanisms may contribute to this observed change, the finding that repeated treatment with haloperidol for 1 month is required for rats to exhibit a higher incidence of coupling is at least consistent with the time course for the induction of DA cell depolarization block and not DA receptor supersensitivity. Furthermore, differences in the effects produced by repeated administration of haloperidol versus clozapine on dye coupling in the motor-related striatal matrix and accumbens core regions is consistent with their differential ability to induce depolarization block in the SN nigrostriatal DA cell group (Chiodo and Bunney, 1983; White and Wang, 1983), which is known to topographically innervate both the matrix and the core regions. In a similar manner, the finding that both antipsychotic drugs increased coupling in the accumbens shell region is also consistent with their ability to induce depolarization block in the VTA mesolimbic DA celı group (Chiodo and Bunney, 1983; White and Wang, 1983), which is known to innervate

$\leftarrow$

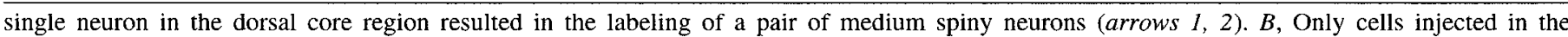

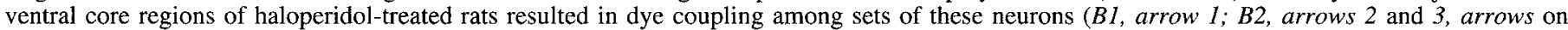

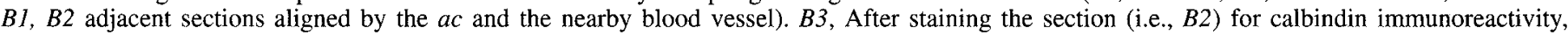

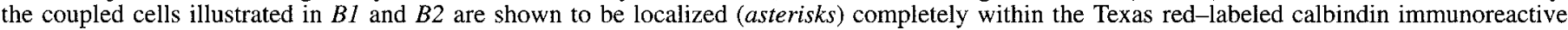

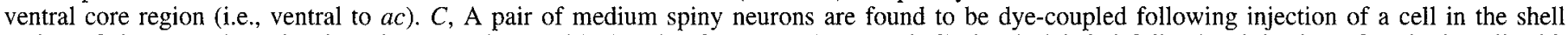

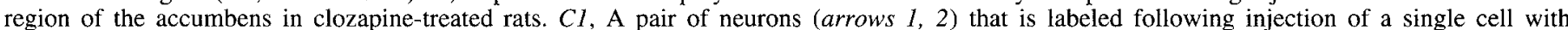

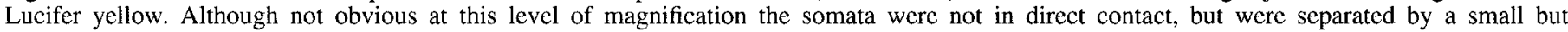

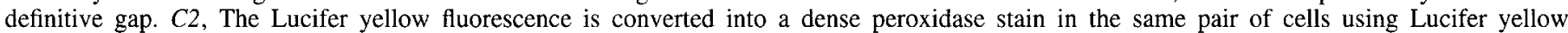

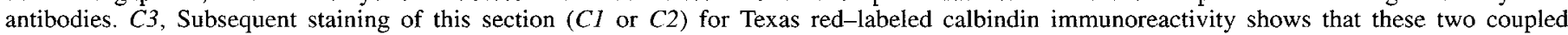

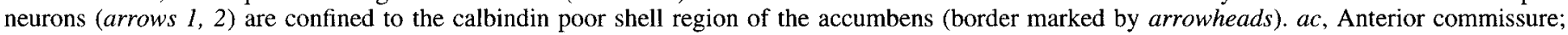
$b v$, blood vessel. Scale bars, $50 \mu \mathrm{m}$. $A$ and $B$ sets refer to bar in $A$ and $C$ set refers to bar in $C 1$. 
Figure 3. The input resistances of neurons recorded in antipsychotic drugtreated rats (i.e., 1 month group) were significantly higher than those of control animals. Injection of constant-current pulses was used to examine the current/voltage relationship of a neuron subsequently revealed to be dye coupled in the accumbens core region of a haloperidol-treated rat $(B)$, or dye coupled in the accumbens shell region of a clozapine-treated rat $(C)$, as compared with that recorded in a dye-coupled cell of a control rat $(A)$. $D$, Plotting the current/voltage relationship enabled calculation of the input resistance from the slope of the regression lines for each cell. As described in Materials and Methods, only the responses to current injections that were subthreshold for evoking spikes were plotted. In these examples, cells from both haloperidol-treated (triangles) and the clozapine treated (squares) rats show higher input resistances than the cell from control rats (circles).

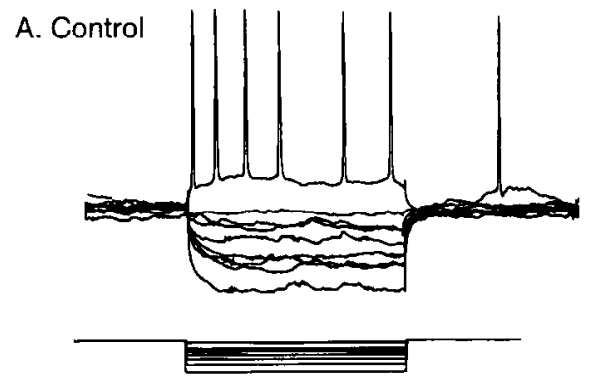

B. Haloperidol
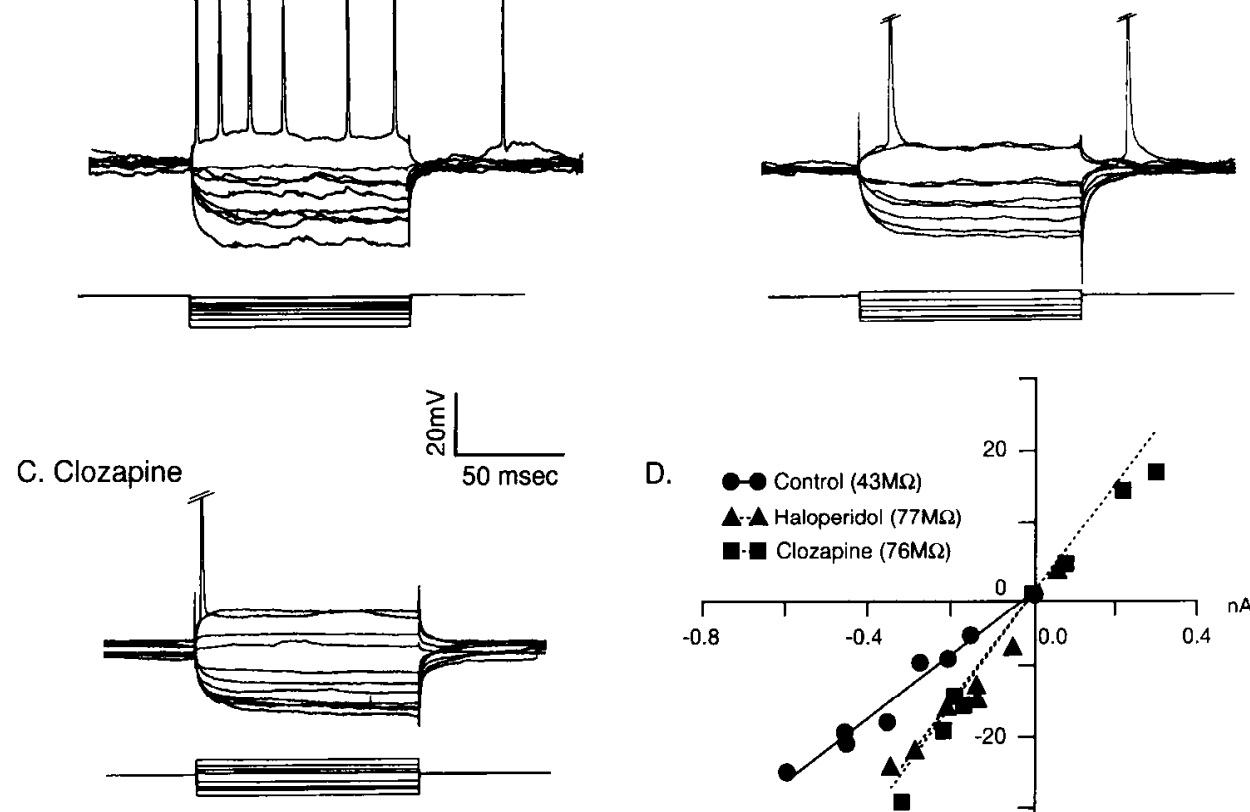

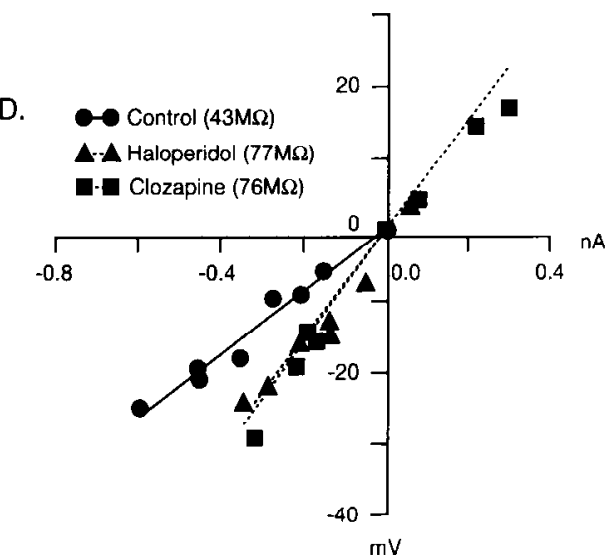

the accumbens shell region (Beckstead et al., 1979; Phillipson and Griffiths, 1985; Voorn et al., 1986; Zahm, 1991). Since these measures were made following a $36 \mathrm{hr}$ drug washout, we also performed a limited number of recordings on a subset of rats treated for 1 month with haloperidol, and confirmed that the DA cells were still in a nonfiring state under these conditions (unpublished observations). Therefore, although DA cell depolarization block was not shown to be causally related to the observed changes in dye coupling, the evidence provides substantial support for this interaction. On the other hand, it is unclear why only a small nonsignificant upregulation of coupling between spiny cells in the accumbens core region was found following repeated clozapine treatment. One possibility may be related to the fact that the core neurons, in addition to receiving mesolimbic DA afferents, also are innervated by DA afferents from the SN A9 DA cell group, which is not inactivated by clozapine. As a result, the effects of APD on coupling between neurons in the core region may depend on a common action of APDs on both SN and VTA neurons, as occurs with haloperidol treatment.

Apparent absence of antipsychotic drug effect on dye coupling between striosomal spiny neurons or aspiny cells

With respect to coupling in the striosomal regions, it is not clear at present why repeated HAL did not alter dye coupling between spiny neurons in this region in a manner comparable to that observed in the matrix, given that both regions receive DA inputs from the SN mesostriatal DA cell group. However, the apparent absence of dye coupling in striosomes and its response to drugs was based on a limited number of observations, primarily due to the comparatively small and irregular volume occupied by the striosomes in the striatal complex (Graybiel and Ragsdale, 1983; Gerfen et al., 1985; Groves et al., 1988; Penny et al., 1988; Desban et al., 1989; Onn et al., 1994c). Therefore, the basal level of coupling and its modulation could not be accurately assessed in this study.

In contrast to striatal spiny cells located in the matrix, coupling has not been observed to occur between cells of the nonspiny cell classes in the striatal complex of control rats. Although a small number of aspiny cells were examined in this study, none of the stained aspiny cells exhibited coupling following treatment with antipsychotic drugs. On the other hand, gap junction-like structures have been reported to be present between at least one class of striatal nonspiny cells (i.e., the parvalbumin-immunoreactive aspiny cells; Kita et al., 1990). One possibility is that junctions between cells in this cell class may require a different type of stimulus from those examined to date in order to cause them to be in the "open" state (Onn and Grace, 1993). However, because the nonspiny cell classes comprise only approximately $1-5 \%$ of the striatal cells (Pasik et al., 1977, 1979; Preston et al., 1980; Chang and Kitai, 1982; Graybiel and Ragsdale, 1983; Fisher et al., 1986; Wilson et al., 1990; Kawaguchi, 1992), we cannot rule out the possibility that dye coupling is present in at least one subpopulation of these cells.

\section{Changes in the electrophysiological properties of striatal cells following APD administration}

In addition to the changes in coupling observed following APD administration, the striatal cells also exhibited a significant increase in input resistance following repeated $\mathrm{HAL}$ when compared to those recorded in control rats. This increase could not bc attributcd to the presence of coupling since coupled cclls and noncoupled cells in the striatum of treated rats showed similar increases in input resistances. Similarly, in control rats no difference was found between the input resistance of cells that were subsequently found to be coupled and those that did not show coupling in either the present study or in our previous report (Onn and Grace, 1994a). The alteration of striatal cell input re- 
sistance was not reported in striatal cells recorded in vitro following a similar regimen of haloperidol treatment (Calabresi et al., 1992). This discrepancy could reflect differences in several factors that are likely to exert disparate influences in each preparation, such as: (1) differences in DA cell activity such as depolarization block, which is dependent on an intact striatonigral feedback pathway (Bunney and Grace, 1978; Chiodo and Bunney, 1983; Grace and Bunney, 1983; White and Wang, 1983; Hollerman et al., 1992); (2) differences in the relative impact of other presynaptic changes present in the in vivo preparation, such as presynaptic D2 receptor supersensitivity (Bannon et al., 1980; Calabresi et al., 1992), changes in corticostriatal transmission (Meshul and Tan, 1993; Meshul et al., 1994), an increase in perforated synapses (Meshul et al., 1992), or a decrease in glutamate receptor binding (Creese et al., 1994).

\section{Summary and conclusions}

Repeated treatment of rats with haloperidol for 1 month or longer, but not for 2 weeks, increased the incidence of dye coupling in the matrix and core regions of the striatal complex, both of which are calbindin positive and are believed to subserve motorrelated functions, as well as in the limbic-related shell region of the nucleus accumbens. In contrast, 1 month of clozapine administration increased coupling only in the shell of the accumbens. Although the specific mechanism underlying this response has not been established directly, several lines of evidence suggest that DA cell depolarization block may play a major role in this response: (1) the time course of the change in dye coupling is correlated with depolarization block but not with APD-induced DA receptor supersensitivity (Burt et al., 1977; Muller and Seeman, 1978; Chiodo and Bunney, 1983; White and Wang, 1983), and (2) the regional specificity in the actions of these classic and atypical APDs corresponds to the ability of these drugs to induce depolarization block in the DA cells projecting to these regions (Chiodo and Bunney, 1983; White and Wang, 1983). One functional impact of this drug-induced increase in coupling among sets of striatal GABAergic projection neurons would be to diminish the variability of activity among cells via the transfer of membrane polarization and second messengers through the putative gap junctions. This in turn would result in a synchronization in their efferent regulation of neurons located in the output nuclei of the basal ganglia. Separate populations of neurons (Feger and Crossman, 1984; Parent et al., 1984; Beckstead et al., 1986; Kawaguchi et al., 1990) in the same matrix compartment (Jimenez-Castellanos and Graybiel, 1989) have been shown to project to each of the three major output sites of the basal ganglia: the globus pallidus, entopeduncular nucleus, and the substantia nigra zona reticulata. Given that the vast majority of striatal spiny cells are GABAergic, electrical coupling would allow a synchronization of activity among cells that would otherwise exhibit only inhibitory interactions (Wilson et al., 1989; Bennett and Bolam, 1994). Such changes in the basic characteristics of neuronal interactions would be expected to have a potent influence on the functional properties of this structure. Consequently, the selective modulation of coupling by antipsychotic drug treatment may actually reflect the clinically relevant actions of these drugs upon administration to the human schizophrenic patient.

\section{References}

Alheid GF, Heimer L (1988) New perspectives in basal forebrain organization of special relevance for neuropsychiatric disorders: the striatopallidal, anygdaloid and corticopetal components of substantia innominata. Neuroscience 27:1-39.

Andrew RD, MacVicar BA, Dudek FE, Hatton GI (1981) Dye transfer through gap junctions between neuroendocrine cells of rat hypothalamus. Science 211:1187-1189.

Andrew RD. Taylor CP, Snow RW, Dudek FE (1982) Coupling in rat hippocampal slices: dye transfer between CAl pyramidal cells. Brain Res Bull 8:211-222.

Arbuthnott GW, Brown JR, Kapoor W, Whale D (1981) Presynaptic actions and dopamine in the neostriatum. In: The basal ganglia, structure and function (McKenzie JS, Kemm RE, Wilcock LN, eds), pp 173-203. New York: Plenum.

Arts MPM, Groenewegen HJ (1992) Relationships of the dendritic arborizations of ventral striatomesencephalic projection neurons with boundaries of striatal compartments: an in vitro intracellular labeling study in the rat. Eur J Neurosci 4:574-588.

Baldessarini RJ, Tarsy D (1980) Pathological basis of tardive dyskinesia. Adv Biochem Psychopharmacol 24:451-455.

Bannon MJ, Bunney EB, Zigun JR, Skirboll LR, Roth RH (1980) Presynaptic dopamine receptors: insensitivity to kainic acid and the development of supersensitivity following chronic haloperidol. NaunynSchmiedeberg's Arch Pharmacol 312:161-165.

Beckstead RM, Cruz CJ (1986) Striatal axons to the globus pallidus, entopeduncular nucleus and substantia nigra come mainly from separate cell populations in cat. Neuroscience 19:147-158.

Beckstead RM, Domesick VB, Nauta WJH (1979) Efferent connections of the substantia nigra and ventral tegmental area in the rat. Brain Res 175:191-217.

Bennett BD, Bolam JP (1994) Synaptic input and output of parvalbumin-immunoreactive neurons in the neostriatum of the rat. Neurosci 62:707-719.

Berendse HW, Galis-de Graaf Y, Groenewegen HJ (1992) Topographical organization and relationship with ventral striatal compartments of prefrontal corticostriatal projections in the rat. J Comp Neurol 316: 314-347.

Bernardi G, Calabresi P, Mercuri N, Stanzione P (1984) Dopamine decreases the amplitude of excitatory postsynaptic potentials in rat striatal neurons. In: The basal ganglia, structure and function (McKenzie IS, Kemm RE, Wilcock I.N, eds), pp 161-171. New York: Plenum.

Bishop GA, Chang HT, Kitai ST (1982) Morphological and physiological properties of neostriatal ncurons: an intracellular horseradish peroxidase study in the rat. Neuroscience 7:179-191.

Bunney BS, Grace AA (1978) Acute and chronic haloperidol treatment: comparison of effects on nigral dopamine cell activity. Life Sci 23:1715-1728.

Burt DR, Creese I, Snyder SH (1977) Antischizophrenic drugs: chronic treatment elevates dopamine receptor binding in brain. Science 196 326-328.

Calabresi P, Mercuri N, Stanzione P, Stefani A, Bernardi G (1987) Intracellular studies on the dopamine-induced firing inhibition of neostriatal neurons in vitro: evidence for D1 receptor involvement. Neuroscience 20:757-771.

Calabresi P, Benedetti M, Mercuri NB, Bernardi G (1988) Endogenous dopamine and dopaminergic agonists modulate synaptic excitation in neostriatum: intracellular studies from naive and catecholamine-depleted rats. Neuroscience 27:145-157.

Calabresi P, De Murtas M, Mercuri NB, Bernardi G (1992) Chronic neuroleptic treatment: D2 dopamine receptor supersensitivity and striatal glutamatergic transmission. Ann Neurology 31:366-373.

Carlsson A, Lindqvist M (1963) Effect of chlorpromazine or haloperidol on formation of 3-methoxytyramine and normetanephrine in mouse brain. Acta Pharmacol Toxicol 20:140-145.

Celio MR (1990) Calbindin D-28K and parvalbumin in the rat nervous system. Neuroscience 35:375-475.

Cepeda C, Walsh JP, Hull CD, Buchwald NA, Levine MS (1989) Dyecoupling in the neostriatum of the rat. I. Modulation by dopamine depleting lesions. Synapse 4:229-237.

Chang HT, Kitai ST (1982) Large neostriatal neurons in the rat: an electron microscopic study of gold-toned Golgi-stained cells. Brain Res Bull 8:631-643.

Chang HT, Wilson CJ, Kitai ST (1982) A golgi study of rat neostriatal neurons: light microscopic analysis. J Comp Neurol 208:107-126.

Chiodo LA, Bunney BS (1983) Typical and atypical neuroleptics: dif- 
ferential effects of chronic administration on the activity of $\wedge 9$ and A10 midbrain dopaminergic neurons. J Neurosci 3:1607-1619.

Cools AR, Kikuchi de Beltran K, Prinssen E, Koshikawa N (1993) Differential role of core and shell of the nucleus accumbens in jaw movements of rats. Neurosci Res Commun 13:55-61.

Cooper SJ, Leahey W, Liddle J, King DJ (1990) The relationship between clinical and biochemical changes following neuroleptic treatment in schizophrenia. Schizophrenia Res 3:261-267.

Cotes PM, Crow TJ, Johnstone EC, Bartlett W, Bourne RC (1978) Neuroendocrine changes in acute schizophrenia as a function of clinical state and neuroleptic medication. Psychol Med 8:657-665.

Creese I, Burt DR, Snyder SH (1976) Dopamine receptor binding predicts clinical and pharmacological potencies of antischizophrenic drugs. Science 192:481-483.

Creese I, Tarazi FI, Florijn WJ (1994) Rcgulation of glutamate receptor binding following chronic neuroleptic treatment. Soc Neurosci Abstr 20:1772.

Davis JM, Garver DL (1978) Neuroleptics: clinical use in psychiatry. In: Handbook of psychopharmacology, Vol 10 (Iverson LL, Iverson DA, Snyder SH, eds), pp 131-164, New York: Plenurn.

Desban M, Gauchy C, Kemel ML, Besson MJ, Glowinski J (1989) Three-dimensional organization of the striosomal compartment and patchy distribution of striatonigral projection in the matrix of the cat caudate nucleus. Neuroscience 29:551-566.

Deutch AY, Cameron DS (1992) Pharmacological characterization of dopamine systems in the nucleus accumbens core and shell. Neuroscience 46:49-56.

DiFiglia M, Pasik P, Pasik T (1976) A Golgi study of neuronal types in the neostriatum of nnonkeys. Brain Res 1 14:245-256.

Donoghue JP, Herkenham M (1986) Neostriatal projections from individual cortical fields conform to histochemically distinct striatal compartments in the rat. Brain Res 365:397-403.

Dudek FE, Andrew RD, MacVicar BA, Snow RW, Taylor CP (1983) Recent evidence and possible significance of gap junctions and electrotonic synapses in the mammalian brain In: Basic mechanisms of neuronal hyperexcitability (Jasper HH, van Gelder NM, eds), pp 3173. New York: Liss.

Fairley PC, Marshall JF (1986) Dopamine in the lateral caudate-putamen of the rat is essential for somatosensory orientation. Behav Neurosci 100:652-663.

Feger J, Crossman AR (1984) Identification of different subpopulations of neostriatal neurons projecting to globus pallidus or substantia nigra in the monkey: a retrograde fluorescence double-labeling study. Neurosci Lett 49:7-12.

Fisher RS, Buchwald NA, Hull CD, Levine MS (1986) The GABAergic striatonigral neurons of the cat: demonstration by double peroxidase labeling. Brain Res 398:148-156.

Florijn WI, Tarazi FI, Creese I (1994) Dopamine "D2" receptor antagonist radioligands: differences in receptor binding following chronic neuroleptic treatment. Satellite Meeting of the XII International Congress of Pharmacology: Dopamine '94; Quebec City, Canada. Session II Receptors.

Francois C, Yelnik J, Percheron G, Tande D (1994) Calbindin D-28K as a marker for the associative cortical territory of the striatum in macaque. Brain Res 633:331-336.

Gerfen CR (1984) The neostriatal mosaic: compartmentalization of corticostriatal input and striatonigral output systems. Nature 311:461464.

Gerfen CR, Baimbridge KG, Miller JJ (1985) The neostriatal mosaic: compartmental distribution of calcium-binding protein and parvalbumin in the basal ganglia of the rat and monkey. Proc Natl Acad Sci USA 82:8780-8784.

Gerfen CR, Herkenham M, Thibault J (1987) The neostriatal mosaic. II. Patch/matrix-directed mesostriatal dopaminergic and non-dopaIninergic systems. J Neurosci 7:3915-3934.

Gerlach J, Koppelhus P, Jelweg E, Monrad A (1974) Clozapine and haloperidol in a single-blind cross-over trial: therapeutic and biochemical aspects in the treatment of schizophrenia. Acta Psychiat Scand 50:410-424.

Goldman-Rakic PS (1982) Cytoarchitectonic heterogeneity of the primate neostriatum: subdivision into island and matrix cellular compartments. J Comp Neurol 205:398-413.

Grace AA, Bunney BS (1983) Intracellular and extracellular electrophysiology of nigral dopaminergic neurons. 3. Evidence for electrotonic coupling. Neuroscience 10:333-348.
Grace $\Lambda$ ^, Bunney BS (1986) Induction of depolarization block in midbrain dopamine neurons by repeated administration of haloperidol: analysis using in vivo intracellular recording. J Pharmacol Exp Ther 283:1092-1 100.

Grace AA, Llinás R (1985) Dehydration-induced morphological artifacts in intracellularly stained neurons: circumvention using rapid DMSO clearing. Neuroscience 16:461-475.

Grace AA, Onn S-P (1989) Morphology and electrophysiological properties of immunocytochemically identified rat dopamine neurons recorded in vitro. J Neurosci 9:3463-3481.

Graybiel AM (1990) Neurotransmitters and neuromodulators in the basal ganglia. Trends Neurosci 13:244-254.

Graybiel AM, Ragsdale CW Jr (1978) Histochemically distinct compartments in the striatum of human, monkey and cat demonstrated by acctylcholinesterase staining. Proc Natl Acad Sci USA 75:57235726.

Graybiel AM, Ragsdale CW Jr (1983) Biochemical anatomy of the striatum. In: Chemical neuroanatomy (Emson PC, ed), pp 427-504. New York: Raven.

Groves PM, Martone M, Young SJ, Armstrong DM (1988) Three dimensional pattern of enkephalin-like immunoreactivity in the caudate nucleus of the cat. J Neurosci 8:892-900.

Gutnick MJ. Prince DA (1981) Dye-coupling and possible electrotonic coupling in the guinea-pig neocortical slice. Science 211:67-70.

Gutnick MJ, Lobel-Yaakov R, Rimon G (1985) Incidence of neuronal dye-coupling in neocortical slices depends on the plane of section. Neuroscience 15:659-666.

Heimer L, Zahm DS, Churchill L, Kalivas PW, Wohltman C (1991) Specificity in the projection patterns of accumbal core and shell in the rat. Neuroscience 41:89-125.

Hollerman JR, Abercrombie ED, Grace AA (1992) Electrophysiological, biochemical, and behavioral studies of acute haloperidol-induced depolarization block of nigral dopamine neurons in rats after partial dopamine lesions. Neuroscience 47:589-601.

Jimenez-Castellanos J, Graybiel AM (1989) Compartmental origins of striatal efferent projections in the cat. Neuroscience $32: 297-321$.

Johnstone EC, Crow TJ, Frith CD, Carney MWP, Price JS (1978) Mechanism of the antipsychotic effect in the treatment of acute schizophrenia. Lancet $1: 848-851$

Kane J, IIonigfeld G, Singer J, Meltzer II (1988) Clozapine for the treatment-resistant schizophrenia. Arch Gen Psychiat 45:789-796.

Kawaguchi $Y$ (1992) Large aspiny cells in the matrix of the rat neostriatum in vitro: physiological identification, relation to the compartments and excitatory postsynaptic currents. J Neurophysiol 67 : 1669-1682.

Kawaguchi Y, Wilson CJ, Emson PC (1990) Projection subtypes of rat neostriatal matrix cells revealed by intracellular injection of biocytin. J Neurosci 10:3421-3488.

Kebabian JW, Calne DB (1979) Multiple receptors for dopamine. Nature 277:93-96.

Kita H, Kosaka T, Heizmann CW (1990) Parvalbumin-immunoreactive neurons in the rat neostriatum: a light and electron microscopic study. Brain Res. 536:1-15.

Kobayashi RM, Fields JZ, Hruska RE, Beaumont K, Yamamura HI (1978) Brain neurotransmitter receptors and chronic antipsychotic drug treatment: a model for tardive dyskinesia: In: Animal models in psychiatry (Usdin E, ed), pp 405-409. New York: Pergamon.

Llinás RR (1985) Electrotonic transmission in the mammalian central nervous system. In: Gap junctions (Bennett MVL, Spray DC, eds), pp 337-353. Cold Spring Harbor, NY: Cold Spring Harbor Laboratory.

MacVicar BA, Dudek FE (1981) Electrotonic coupling between pyramidal cells. A direct demonstration in rat hippocampal slices. Science 213:782-785.

MacVicar BA, Dudek FE (1982) Electrotonic coupling between granule cells of rat dentate gyrus: physiological and anatomical evidence. J Neurophysiol 47:579-592.

Maura G, Giardi A, Raiteri M (1988) Release-regulating D2 dopamine receptors are located on striatal glutamatergic nerve terminals. J Pharmacol Exp Ther 247:680-684.

Meredith GE, Pennartz CMA, Groenewegen HJ (1994) The cellular framework for chemical signaling in the nucleus accumbens. In: Progress in brain research, Vol 99, Chap 1 (Arbuthnott GW, Emson PC, eds), pp 3-24. Amsterdam: Elsevier.

Meshul CK, Tan SE (1993) Haloperidol-induced morphological alter- 
ations are associated with changes in calcium/calmodulin kinase II activity and glutamate immunoreactivity. Soc Neurosci Abstr 19: 1586.

Meshul CK, Janowsky A, Casey DE, Stallbaumer RK, Taylor B (1992) Effect of haloperidol and clozapine on the density of perforated synapses in caudate, nucleus accumbens, and medial prefrontal cortex. Psychopharmacology 106:45-52.

Meshul CK, Stallbaumer RK, Taylor B, Janowsky A (1994) Haloperidol-induced morphological changes in striatum are associated with glutamate synapses. Brain Res 648:181-195.

Mitchell PR, Doggett NS (1980) Modulation of striatal [ $\left.{ }^{3} \mathrm{H}\right]$-glutamic acid release by dopaminergic drugs. Life Sci 26:2073-2081.

Mogenson GJ, Swanson LW, Wu M (1980) From motivation to action: functional interface between the limbic system and the motor system. Prog Neurobiol 14:69-97.

Muller P, Seeman P (1978) Dopaminergic supersensitivity after neuroleptics: time-course and specificity. Psychopharmacology 60:1-11.

O'Beirne M, Bullock AG, MacVicar BA (1987) Dye and electrotonic coupling between cultured hippocampal neurons. Neurosci Lett 78 : $265-270$.

O'Dell SJ, LaHoste GJ, Widmark CB, Shapiro RM, Potkin SG, Marshall JF (1990) Chronic treatment with clozapine or haloperidol differentially regulates dopamine and serotonin receptors in rat brain. Synapse 6:146-153.

O’Donnell P, Grace AA (1993) Dopaminergic modulation of dye coupling between neurons in the core and shell regions of the nucleus accumbens. J Neurosei 13:3456-3471.

O'Donnell P, Grace AA (1994) Tonic D2-mediated attenuation of cortical excitation in nucleus accumbens neurons recorded in vitro. Brain Res 634:105-112.

Onn S-P, Grace AA (1993) Effects of dopamine depletion on dye- and tracer-coupling between spiny cells and between aspiny cells in striatum. Soc Neurosci Abstr 19:977.

Onn S-P, Grace AA (1994a) Dye coupling between rat striatal neurons recorded in vivo: compartmental organization and modulation by dopamine. J Neurophysiol 71:1917-1934.

Onn S-P, Grace AA (1994b) Repeated treatment with typical and atypical neuroleptics enhances electrotonic neurotransmission in the ventral corticostriatal regions. Soc Neurosei Abstr 20:565.

Onn S-P, Grace AA (1994c) Differential effects of typical vs atypical neuroleptics on electrotonic neurotransmission in the matrix and core regions of the striatal complex. Neuropsychopharmacology, XIXth Collegium Internationale Neuro-Psychopharmacologicum Congress. Washington, DC: Elsevier.

Onn S-P, Berger TW, Grace AA (1990) Properties of striatal Type I and Type II cells: incidence of dye-coupling and their localization in patch and matrix compartments in the rat striatum in vivo. Dopamine synthesis and regulation. Italy.

Onn S-P, Berger TW, Grace AA (1994a) Identification and characterization of striatal cell subtypes using in vivo intracellular recording in rats. I. Basic physiology and response patterns to corticostriatal fiber stimulation. Synapse 16:161-180.

Onn S-P, Berger TW, Grace AA (1994b) Identification and characterization of striatal cell subtypes using in vivo intracellular recording in rats. II. Membrane factors underlying paired pulse response profiles. Synapse 16:195-210.

Onn S-P, Berger TW, Grace AA (1994c) Identification and characterization of striatal cell subtypes using in vivo intracellular recording and dye labeling in rats. III. Morphological correlates and compartmental organization. Synapse 16:231-254.

Parent A, Bouchend C, Smith Y (1984) The striatopallidal and striatonigral projections: two distinct fiber systems in primate. Brain Res 303:385-390

Pasik T, Pasik P, DiFiglia M (1977) Interneurons in the neostriatum of monkey. In: The neuron concept (Szcntagothai J, Hamon J, Vizi ES, eds), pp 153-162. Budapest: Akademai Kiado.

Pasik P, Pasik T, DiFiglia M (1979) The internal organization of the neostriatum in mammals. In: The neostriatum (Divac I, Oberg RGE, eds), pp 5-36. New York: Pergamon.

Penny GR, Wilson CJ, Kitai ST (1988) Relationship of the axonal and dendritic geometry of spiny projection neurons to the compartmental organization of the neostriatum. J Comp Neurol 269:275-289

Phelan KD. Twery MJ, Gallagher JP (1993) Morphological and electrophysiological evidence for electrotonic coupling of rat dorsolateral septal nucleus neurons in vitro. Synapse 13:39-49.
Phillipson OT, Griffiths AC (1985) The topographic order of inputs to nucleus accumbens in the rat. Neuroscience 16:275-296.

Pickar D, Labarca R, Linnoila M, Roy A, Hommer D, Everestt D, Paul SM (1984) Ncuroleptic-induced decrease in plasma homovanillic acid and antipsychotic activity in schizophrenic patients. Science 225 : 945-957.

Pisa M, Schranz JA (1988) Dissociable motor roles of the rat's striatum conform to a somatotopic model. Behav Neurosci 102:429-440.

Preston RJ, Bishop GA, Kitai ST (1980) Medium spiny neuron projection from the rat striatum: an intracellular horseradish peroxidase study. Brain Res 183:253-263.

Prinssen EPM, Balestra W, Bemelmans FFJ, Cools AR (1994) Evidence for a role of the shell of the nucleus accumbens in oral behavior of freely moving rats. J Neurosci 14: :555-1562.

Rowlands GJ, Roberts PH (1980) Activation of dopamine receptors inhibits calcium-dependent glutamate release from corticostriatal terminals in vitro. Eur J Pharmacol 62:241-242.

Rupniak NMJ, Jenmer P, Marsden CD (1983) The effect of chronic neuroleptic administration on cerebral dopamine receptor function. Life Sci 32:2289-2311.

Rupniak NMJ, Hall MD, Mann S, Fleminger S, Kilpatrick $G$, Jenner $P$ Marsden CD (1985) Chronic treatment with clozapine, unlike haloperidol does not induce changes in striatal D-2 receptor function in the rat. Biochem Pharmacol 34:2755-2763.

Sedvall G, Garde L, Perrson A, Wiesel FA (1986) Imaging of neurotransmitter receptors in the living human brain. Arch Gen Psychol 43:995-1005.

See RE, Aravagiri M, Ellison GD (1989) Chronic neuroleptic treatment in rats produced persisting changes in $\mathrm{GABA}_{\mathrm{A}}$ and dopamine $\mathrm{D}_{2}$ but not $D_{1}$ receptors. Life Sci 44:229-236.

See RE, Sorg BA, Lynch AM (1994) Decrease in dopamine D2 receptor mRNA levels in the nucleus accumbens following subchronic antipsychotic drug administration in rats. Soc Neurosci Abstr 20:225.

Seeman P, Lee T, Chau-Wong M, Wong K (1976) Antipsychotic drug doses and neuroleptic/dopamine receptors. Nature 261:717-719.

Spohn HE, Lacoursiere RB, Thompson K, Coyne L (1977) Phenothiazine effects on psychological and psychophysiological dysfunction in chronic schizophrenics. Arch Gen Psychol 34:633-644.

Tarazi FJ, Florijn WI, Creese I (1994) Regulation of dopamine receptor binding following chronic neuroleptic treatment. Soc Neurosci Abstr 20:1772.

Voorn P, Jorritsma-Byham B, Van Dijk C, Buijs RM (1986) The dopantinergic innervation of the ventral striatum in the rat: a light and electron microscopical study with antibodies against dopamine. J Comp Neurol 251:84-99.

Voorn P, Gerfen CR, Groenewegen HJ (1989) Compartmental organization of the ventral striatum of the rat: immunohistochemical distribution of enkephalin, substance $\mathbf{P}$, dopamine and calcium binding protein. J Comp Neurol 289:189-201.

Walsh JP, Cepeda C, Hull CD, Fisher RS, Levine MS, Buchwald NA (1989) Dye-coupling in neostriatum of the rat. II. Decreased coupling between neurons during development. Synapse 4:238-247.

Whishaw IQ, Tomie J-A (1987) Cholinergic receptor blockade produces impairments in a sensorimotor subsystem for place navigation in the rat: evidence from sensory, motor, and acquisition tests in a swimming pool. Behav Neurosci 101:603-616.

White NM (1989) A functional hypothesis concerning the striatal matrix and patches: mediation of S-R memory and reward. Life Sci 45: 1943-1957.

White FJ, Wang RY (1983) Differential effects of classical and atypical antipsychotic drugs on A9 and A10 dopamine neurons. Science 221: 1054-1057.

Wilmot CA, Szczepanik AM (1989) Effects of acute and chronic treatments with clozapine and haloperidol on serotonin and dopamine D2 receptors in the rat brain. Brain Res 487:288 298.

Wilson CJ, Kita H, Kawaguchi Y (1989) GABAergic interneurons, rather than spiny cell axon collaterals, are responsible for the IPSP responses to afferent stimulation in neostriatal neurons. Soc Neurosci Abstr 15:907.

Wilson CJ, Chang HT, Kitai ST (1990) Firing patterns and synaptic potentials of identified giant aspiny interneurons in the rat neostriatum. J Neurosci 10:508-519.

Yelnik J, Francois C, Percheron G, Tande D (1991) Morphological taxonomy of the neurons of the primate striatum. J Comp Neurol 313:273-294. 
7ahm DS (1991) Compartments in rat dorsal and ventral striatum revealed following injection of 6-hydroxydopamine into the ventral mesencephalon. Brain Res 552:164-169.

Zahm DS (1992) An electron microscopic morphometric comparison of tyrosine hydroxylase immunoreactive innervation in the neostriatum and the nucleus accumbens core and shell. Brain Res 575:341346.
Zahm DS, Heimer L (1988) Ventral striatopallidal parts of the basal ganglia in the rat. I. Neurochemical compartmentation as reflected by the distributions of neurotensin and substance $\mathbf{P}$ immunoreactivity. $\mathrm{J}$ Comp Neurol 271:516-535.

Zahm DS, Heimer L (1990) Two transpallidal pathways originating in nucleus accumbens. J Comp Neurol 302:437-446. 